\title{
The Multi Attribute Utility Theory (Death) Method In The Decision Of The Distributor Distributor Selection (Metode Multi Attribute Utility Theory (Maut) Dalam Keputusan Pemilihan Distributor Barang)
}

\author{
Ritna Wahyuni ${ }^{1}$, Sarjon Defit ${ }^{2}$,Gunadi Widi Nurcahyo ${ }^{2}$ \\ Universitas Putra Indonesia YPTK Padang \\ E-mail: ritna140676wahyuni@yahoo.co.id
}

\begin{abstract}
Abstrak
Distributor adalah perantara yang menyalurkan produk dari pabrik ke pengecer. Sedangkan distributor barang yaitu penyalur barang dari pabrik ke toko-toko yang membutuhkan barang tersebut. Pemilihan distributor yang tidak tepat dapat mengganggu proses penjualan pada pihak toko. Untuk meningkatkan kualitas dan mutu dari sebuah toko tersebut maka dibutuhkan distributor barang terbaik. Penelitian ini bertujuan untuk menentukan distributor barang yang terbaik. Metode yang digunakan adalah Multi Attribute Utility Theory (MAUT) terhadap data distributor pada Toko Serba Serbi Padang Luar. Data yang diolah dalam penelitian ini terdiri dari beberapa data distributor yang dipilih oleh pihak Toko Serba Serbi. Dari beberapa data distributor tersebut maka Sistem Pendukung Keputusan sangat diperlukan dalam pemilihan distributor yang bertujuan untuk pemilihan alternatif keputusan yang tepat. Pemilihan distributor menggunakan 15 sampel data distributor dan 5 data kriteria yang dijadikan dasar dalam pemilihan distributor yaitu kualitas barang, harga terjangkau, tempat strategis, respon pelayanan, dan memberikan bonus. Hasil dari pengujian terhadap metode ini didapatkan tingkat akurasi yaitu $86,67 \%$ terhadap distributor yang tepat dan sesuai dengan realisasi data uiji. Sehingga penelitian ini sanga cocokt dalam pemilihan distributor yang terbaik. Dari hasil pengujian telah mendapatkan 5 distibutor yang terbaik dengan menetapkan bobot 11,50 terhadap distributor yang terbaik, maka kriteria yang ditetapkan Toko Serba Serbi dapat dijadikan acuan dalam pemilihan distributor barang.
\end{abstract}

Kata kunci: Distributor Barang, Keputusan, MAUT, Toko Serba Serbi

\begin{abstract}
Abstrak
Distributors are intermediaries who distribute products from factories to retailers. While the distributor of goods is the distributor of goods from factories to shops that need these goods. Incorrect selection of distributors can interfere with the sales process at the store. To improve the quality and quality of a store, it requires the best distributor of goods. This study aims to determine the best distributor of goods. The method used is the Multi Attribute Utility Theory (MAUT) of distributor data at the Padang Luar Sundanese Convenience Store. The data processed in this study consisted of a number of distributor data selected by the Multipurpose Store. From some of the distributor data, the Decision Support System is very necessary in the selection of distributors who aim for the selection of appropriate alternative decisions. The selection of distributors uses 15 samples of distributor data and 5 criteria data that are used as the basis for selecting distributors, namely quality of goods, affordable prices, strategic locations, service responses, and giving bonuses. The results of testing on this method obtained an accuracy rate of $86.67 \%$ of the right distributors and in accordance with the realization of the UI data. So this research is very suitable in choosing the best distributor. From the test results, it has got the 5 best distributors by assigning a weight of 11.50 to the best distributor, so the criteria set by the All-Round Shop can be used as a reference in the selection of distributors of goods.
\end{abstract}

Keywords: Goods Distributor, Decision, DEATH, Convenience Store 


\section{Pendahuluan}

Sistem Pendukung Keputusan mempunyai beberapa model seperti Model Multi Criteria Decision Making (MCDM). Salah satu model MCDM yang dapat membantu dalam pengambilan keputusan adalah metode Multi-Atribut Utility Teori (MAUT), di mana sejumlah kriteria harus diperhitungkan saat membuat keputusan penting (Suner et al, 2017). Memiliki banyak kriteria dan berbagai alternatif merupakan sebuah teknik dalam proses pengambil keputusan menggunakan metode MAUT (Pergher dan Almeida, 2018). Metode MAUT telah banyak digunakan dalam penelitian sebelumnya. Misalnya saja metode MAUT digunakan untuk Penerimaan Bantuan Renovasi Rumah Dhuafa, didapatkan tingkat akurasi mencapai $80 \%$ pada proses seleksi calon penerima bantuan rumah dhuafa (Fajirwan et $a l, 2018$ ). Dengan merujuk pada penelitian sebelumnya, maka penulis ingin membahas suatu masalah pada satu toko yang memiliki masalah dalam pemilihan distributor barang. Pemilihan distributor yang tidak tepat dapat mengganggu proses penjualan pada pihak toko. Untuk meningkatkan kualitas dan mutu dari sebuah toko tersebut maka dibutuhkan distributor barang terbaik. Toko Serba Serbi Padang Luar merupakan sebuah toko yang menjual berbagai macam barang seperti alat-alat listrik, alat-alat pertukangan, dan elektronik. Bagi toko ini distributor barang merupakan salah satu faktor yang paling penting.

\section{Tinjauan Literatur}

\subsection{Multi Attribute Utility Theory (MAUT)}

Multi Attribute Utility Theory (MAUT) merupakan salah satu metode kuantitatif yang dijadikan dasar pengambilan keputusan melalui prosedur sistematis yang mengidentifikasi dan menganalisa beberapa variabel (Fajirwan et al, 2018). Metode MAUT adalah teori utilitas (nilai kepuasan) yang dapat menentukan tindakan terbaik dalam pemecahan masalah dengan menetapkan utilitas untuk setiap alternatif yang mungkin terjadi dan menghitung kemungkinan utilitas terbaik (Nas et al, 2018). MAUT digunakan untuk merubah dari beberapa kepentingan ke dalam nilai numerik dengan skala 0-1 dengan 0 mewakili pilihan terburuk dan 1 terbaik. Hal ini memungkinkan perbandingan langsung yang beragam ukuran (Hadinata, 2018). Teori utilitas mengevaluasi nilai akhir dari suatu objek didefinisikan sebagai bobot yang dijumlahkan dengan suatu nilai yang relevan terhadap nilai dimensinya. Dengan menggunakan metode MAUT, dihasilkan urutan peringkat dari evaluasi alternatif (Nas et al, 2018).

Langkah-langkah dari metode MAUT adalah sebagai berikut (Satria et al, 2018):

1. Pecah sebuah keputusan ke dalam dimensi yang berbeda.

2. Tentukan bobot alternatif pada masing-masing dimensi.

3. Daftar semua alternatif.

4. Masukkan utility untuk masing-masing alternatif sesuai atributnya.

5. Kalikan utility dengan bobot untuk menentukan nilai masing-masing alternatif. Normalisasi matriks:

Di mana :

$$
N(a)=\frac{a-a i^{-}}{a i^{+}-a i^{-}} \ldots \ldots \ldots \ldots \ldots
$$

$N(a) \quad$ : Normalisasi bobot altrenatif $a$

$a \quad$ : Nilai alternatif dari kriteria ke $a$

$a i^{-} \quad$ : Nilai minimum dari kriteria ke $a$

$a i^{+} \quad$ : Nilai maximum dari kriteria ke $a$

Nilai evaluasi seluruhnya dapat didefinisikan dengan persamaan:

$$
A(X)=\sum_{a=1}^{n} W a \cdot U(x) \ldots \ldots \ldots \ldots \ldots
$$


Di mana $A(x)$ yaitu nilai evaluasi ke $(a)$ dan (Wa) merupakan bobot dari setiap kriteria ke $(a), U(x)$ merupakan hasil normalisasi dari setiap kriteria.

Algoritma penyelesaian metode Multi Attribute Utility Theory ini yaitu (Imam et al, 2019):

1. Langkah 1 : Mendefinisikan terlebih dahulu kriteria-kriteria yang akan dijadikan sebagai tolok ukur penyelesaian masalah dan menentukan tingkat kepentingan dari setiap kriteria.

2. Langkah 2 : Menghitung Nilai Matriks Perbandingan dari masing-masing kriteria berdasarkan tabel nilai kepentingan (tabel Saaty).

3. Langkah 3 : Menghitung nilai bobot kriteria.

4. Langkah 4 : Menghitung nilai bobot preferensi.

5. Langkah 5 : Perangkingan.

\section{Metodologi Penelitian}

Metodologi penelitian yang digunakan dalam penyelesaian masalah penelitian. Metodologi penelitian akan sangat membantu penulis dalam proses kerja penyelesaian masalah. Penelitian ini memiliki beberapa tahapan dalam pelaksanaan kegiatan yang tertuang pada kerangka kerja penelitian, yaitu mengidentifikasi masalah, menganalisa masalah, menentukan tujuan, memelajari literatur, mengumulkan data, menganalisa data san mengimplementasikan dengan metode Multi-Atribut Utility Teori (MAUT), menguji hasil, dan pengambilan keputusan.

\subsection{Kerangka Kerja Penelitian}

Kerangka kerja penelitian sangat penting dalam penyelesaian penelitian ini sehingga tidak melenceng dan hasil yang dicapai menjadi lebih maksimal. Urutan kerangka kerja akan dibuat secara teratur sehingga jelas dan mudah dipahami dalam menyelesaikan permasalahan yang ada. Urutan langkahlangkah yang akan dibuat pada penelitian ini dapat dilihat pada gambar 2 Kerangka Kerja Penelitian.

Berdasarkan gambar di bawah ini, maka dapat dijelaskan urutan kerangka kerja Penelitian sebagai berikut:

1. Mengidentifikasi Masalah

Langkah yang dilakukan pada tahap awal ini adalah melakukan peninjauan ulang terhadap permasalahan yang akan diteliti. Untuk menentukan tujuan dan rumusan masalah, serta penerapan Metode MAUT dalam menentukan distributor barang terbaik.

2. Menganalisa Masalah

Langkah menganalisa masalah adalah langkah untuk dapat memahami masalah yang telah ditentukan dalam ruang lingkup atau batasannya. Dengan menganalisa masalah yang ditentukan tersebut, maka masalah dapat dipahami dengan baik. Masalah yang timbul adalah bagaimana menentukan distributor barang terbaik dengan penyelesaian menggunakan metode MAUT.

3. Menentukan Tujuan

Setelah analisis masalah selesai dilakukan, langkah berikutnya adalah menentukan tujuan yang akan dicapai dalam penelitian ini. Hal ini dimaksudkan agar hasil yang didapat nanti tidak akan berbeda dengan keputusan yang akan diambil.

4. Mempelajari Literatur

Agar tujuan penelitian bisa tercapai, maka dipelajarilah beberapa literatur-literatur yang diperkirakan dapat dipakai dalam peyelesaian masalah dalam penelitian ini. Penelitian juga dilakukan melalui buku-buku dan jurnal-jurnal yang ada hubungannya dengan Sistem Pendukung Keputusan serta metode MAUT.

5. Mengumpulkan Data

Pada tahapan ini dilakukan pengumpulan data dengan cara observasi langsung dan wawancara dengan pihak Toko Serba Serbi Padang Luar. Mengumpulkan data yang akurat dan membagi data tersebut ke dalam kriteria yang sudah ditentukan.

6. Menganalisa dan Mengolah Data Dengan metode MAUT 
Langkah selanjutnya yaitu data yang didapat dianalisa dan diolah untuk menghasilkan informasi yang berguna. Tahap ini metode MAUT diterapkan pada pemilihan distributor barang terbaik yang menggunakan data-data distributor.

7. Merancang Sistem Pendukung Keputusan

Setelah proses analisa dan pengolahan data dengan metode MAUT pada tahap ini dilakukan perancangan sistem yang sesuai dengan kriteria distributor pada Toko Serba Serbi. Maka akan dirancang dengan menggunakan Bahasa Pemrograman PHP dan database MySQL.

8. Menguji Sistem Pendukung Keputusan

Setelah sistem dirancang kemudian dibuatkan sebuah aplikasi Sistem Pendukung Keputusan dan setelah itu dapat dilakukan proses pengujian sistem, apakah sistem tersebut layak digunakan atau tidak.

9. Mengimplementasikan Sistem

Implementasi Sistem ini untuk membandingkan hasil yang didapatkan menggunakan metode secara manual dengan sistem komputerisasi. Dalam membangun sebuah sistem yang berbasis komputerisasi ada 2 komponen yang harus dipenuhi.

10. Menguji Hasil

Berdasarkan kriteria yang telah ditentukan dengan menerapkan metode MAUT dilakukan pengujian terhadap data distributor. Dengan cara menguji hasil data menggunakan Metode MAUT seperti mekanisme berikut ini:

1) Menentukan data distributor yang diperoleh dari Toko Serba Serbi.

2) Data distributor kemudian dikelola secara manual menggunakan metode MAUT dengan kriteria dan bobot sudah ditentukan.

3) Hasil yang di peroleh dilakukan pengujian dengan sistem menerapkan metode MAUT menggunakan data distributor yang akan dicocokan keakuratan dengan data yang diolah secara manual.

4) Hasil yang paling tinggi dapat dijadikan acuan dalam pemilihan distributor yang terbaik pada Toko Serba Serbi Padang Luar.

11. Menarik Kesimpulan

Setelah dilakukan pengujian terhadap data distributor menggunakan metode MAUT secara manual maupun sistem yang telah dirancang maka dapat diambil kesimpulan tentang pemilihan distributor barang terbaik pada Toko Serba Serbi Padang Luar.

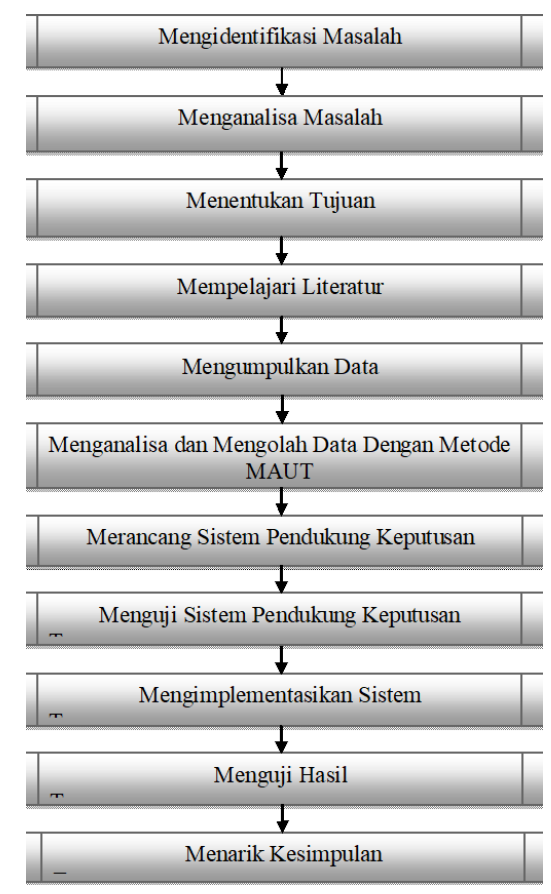




\section{Gambar 2 : Kerangka Kerja Penelitian}

\section{Analisa Dan Perancangan}

Data yang telah dianalisa akan diolah menggunakan metode MAUT mengenai pemilihan distributor barang. Selanjutnya akan dilakukan proses perancangan sistem dalam pembuatan Sistem Pendukung Keputusan untuk menguji apakah proses perhitungan yang dilakukan sudah tepat atau belum. Maka Tahap Analisa dan Perancangan dapat digambarkan seperti Gambar 3 Bagan Alir Analisa dan Perancangan.

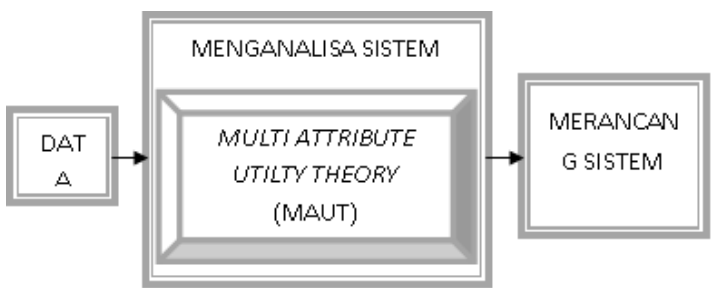

Gambar 3 : Bagan Alir Analisa dan Perancangan

\subsection{Analisa Kebutuhan Data}

Data yang digunakan adalah data yang didapat dari Toko Serba Serbi.

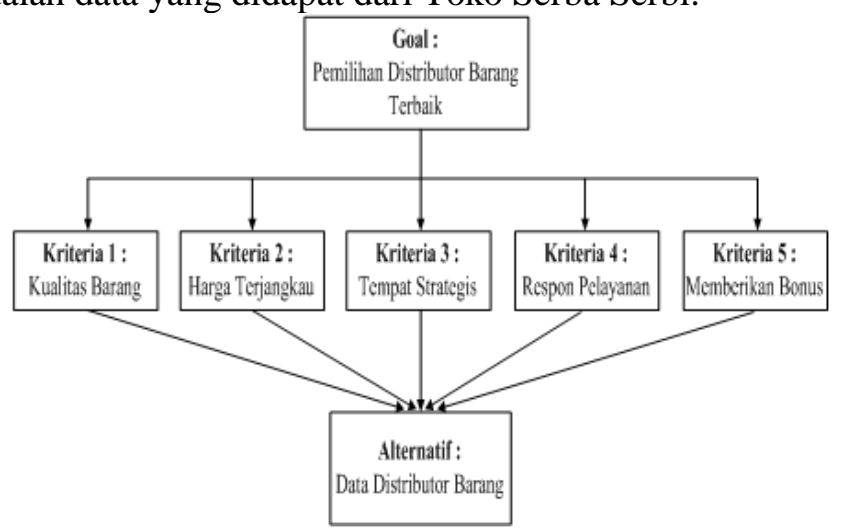

Gambar 4: Blok Diagram Hirarki Sistem Pendukung Keputusan

\subsection{Analisa Data Menggunakan Metode MAUT}

\section{Data Kriteria}

Langkah awal yang dilakukan adalah menentukan kriteria-kriteria dan menentukan bobot pada setiap kriteria yang akan digunakan dalam mengolah data menggunakan metode MAUT. Berikut ini merupakan kriteria dan bobot pada setiap kriteria yang digunakan terdapat pada tabel berikut ini.

Tabel 1 : Kriteria dan Bobot

\begin{tabular}{lll}
\hline No & Kriteria & Bobot Kriteria \\
\hline 1 & Kualitas Barang & 1 \\
\hline 2 & Harga Terjangkau & 2 \\
\hline 3 & Tempat Strategis & 3 \\
\hline 4 & Respon Pelayanan & 4 \\
\hline 5 & Memberikan Bonus & 5 \\
\hline
\end{tabular}




\section{Data Alternatif}

Data alternatif adalah data distributor barang yang didapatkan dari Toko Serba Serbi. Terdapat 15 data alternatif yang dibutuhkan dan akan diproses untuk pemilihan distributor barang terbaik. Berikut ini merupakan data alternatif yang terdapat pada Tabel 4.2.

\section{Tabel 2 : Data Alternatif}

\begin{tabular}{clc}
\hline No. & \multicolumn{1}{c}{ Alternatif } & Inisial Alternatif \\
\hline 1 & Toko DW & A1 \\
\hline 2 & Toko Cemerlang & A2 \\
\hline 3 & Toko Persada Jaya & A3 \\
\hline 4 & Toko BBM & A4 \\
\hline 5 & Toko Sumber Terang & A5 \\
\hline 6 & Toko MM (Maju Mapan) & A6 \\
\hline 7 & Toko Sumber Elektrik & A7 \\
\hline 8 & Toko SP (Sidi Pingai) & A8 \\
\hline 9 & Toko Aneka Jaya & A9 \\
\hline 10 & Toko Amara & A10 \\
\hline 11 & Toko Rahmat Terang & A11 \\
\hline 12 & Toko BR & A12 \\
\hline 13 & Toko Nasional & A13 \\
\hline 14 & Toko Sinar Jelita & A14 \\
\hline 15 & Toko Jasa Saudara & A15 \\
\hline & & \\
\hline
\end{tabular}

\section{Data yang Digunakan}

Nilai kriteria setiap data yang akan digunakan dalam mengolah data menggunakan metode MAUT ini adalah data yang peneliti dapatkan dari hasil wawancara dengan pihak toko. Berikut ini merupakan data penilaian yang diberikan pada setiap kriteria yang akan diolah terdapat pada tabel berikut ini.

\section{Tabel 3 : Data Penilaian Kriteria}

\begin{tabular}{clc}
\hline No & \multicolumn{1}{c}{ Keterangan } & Nilai \\
\hline 1 & Tidak Bagus & 1 \\
\hline 2 & Kurang Bagus & 2 \\
\hline 3 & Cukup Bagus & 3 \\
\hline 4 & Bagus & 4 \\
\hline 5 & Sangat Bagus & 5 \\
\hline
\end{tabular}

Data penilaian setiap alternatif berdasarkan kriteria yang telah di tentukan oleh pihak toko. Berikut ini merupakan data penilaian kriteria dari masing-masing alternatif yang terdapat pada Tabel 4.4. 
Tabel 4 : Data Penilaian Kriteria dari Masing-Masing Alternatif

\begin{tabular}{|c|c|c|c|c|c|c|}
\hline No & Alternatif (A) & $\begin{array}{c}\text { Kualitas } \\
\text { Barang }\end{array}$ & $\begin{array}{c}\text { Harga } \\
\text { Terjangkau }\end{array}$ & $\begin{array}{c}\text { Tempat } \\
\text { Strategis }\end{array}$ & $\begin{array}{c}\text { Respon } \\
\text { Pelayanan }\end{array}$ & $\begin{array}{c}\text { Memberik } \\
\text { an Bonus } \\
\end{array}$ \\
\hline 1 & Toko DW & Bagus & Sangat bagus & Bagus & Cukup bagus & $\begin{array}{l}\text { Cukup } \\
\text { bagus }\end{array}$ \\
\hline 2 & Toko Cemerlang & $\begin{array}{l}\text { Cukup } \\
\text { bagus }\end{array}$ & Kurang bagus & $\begin{array}{l}\text { Kurang } \\
\text { bagus }\end{array}$ & Cukup bagus & $\begin{array}{l}\text { Cukup } \\
\text { bagus }\end{array}$ \\
\hline 3 & $\begin{array}{l}\text { Toko Persada } \\
\text { Jaya }\end{array}$ & Bagus & Cukup bagus & Bagus & Cukup bagus & $\begin{array}{c}\text { Kurang } \\
\text { bagus }\end{array}$ \\
\hline 4 & Toko BBM & Bagus & Cukup bagus & $\begin{array}{l}\text { Cukup } \\
\text { bagus }\end{array}$ & Cukup bagus & Bagus \\
\hline 5 & $\begin{array}{l}\text { Toko Sumber } \\
\text { Terang }\end{array}$ & $\begin{array}{l}\text { Cukup } \\
\text { bagus }\end{array}$ & Kurang bagus & $\begin{array}{l}\text { Cukup } \\
\text { bagus }\end{array}$ & Bagus & $\begin{array}{c}\text { Kurang } \\
\text { bagus }\end{array}$ \\
\hline 6 & $\begin{array}{l}\text { Toko MM (Maju } \\
\text { Mapan) }\end{array}$ & $\begin{array}{l}\text { Cukup } \\
\text { bagus }\end{array}$ & Cukup bagus & $\begin{array}{c}\text { Kurang } \\
\text { bagus }\end{array}$ & Cukup bagus & $\begin{array}{l}\text { Tidak } \\
\text { bagus }\end{array}$ \\
\hline 7 & $\begin{array}{l}\text { Toko Sumber } \\
\text { Elektrik }\end{array}$ & $\begin{array}{l}\text { Sangat } \\
\text { bagus }\end{array}$ & Bagus & Bagus & Cukup bagus & $\begin{array}{l}\text { Cukup } \\
\text { bagus }\end{array}$ \\
\hline 8 & $\begin{array}{l}\text { Toko SP (Sidi } \\
\text { Pingai) }\end{array}$ & Bagus & Cukup bagus & $\begin{array}{l}\text { Cukup } \\
\text { bagus }\end{array}$ & Bagus & $\begin{array}{l}\text { Cukup } \\
\text { bagus }\end{array}$ \\
\hline 9 & Toko Aneka Jaya & $\begin{array}{l}\text { Cukup } \\
\text { bagus }\end{array}$ & Bagus & Bagus & Cukup bagus & $\begin{array}{l}\text { Cukup } \\
\text { bagus }\end{array}$ \\
\hline 10 & Toko Amara & Bagus & Cukup bagus & Bagus & Cukup bagus & $\begin{array}{l}\text { Cukup } \\
\text { bagus }\end{array}$ \\
\hline 11 & $\begin{array}{l}\text { Toko Rahmat } \\
\text { Terang }\end{array}$ & Bagus & Cukup bagus & Bagus & Bagus & $\begin{array}{l}\text { Cukup } \\
\text { bagus }\end{array}$ \\
\hline 12 & Toko BR & Bagus & Bagus & $\begin{array}{l}\text { Cukup } \\
\text { bagus }\end{array}$ & Bagus & $\begin{array}{l}\text { Cukup } \\
\text { bagus }\end{array}$ \\
\hline 13 & Toko Nasional & $\begin{array}{l}\text { Cukup } \\
\text { bagus }\end{array}$ & Cukup bagus & Bagus & Bagus & $\begin{array}{l}\text { Cukup } \\
\text { bagus }\end{array}$ \\
\hline 14 & Toko Sinar Jelita & $\begin{array}{l}\text { Sangat } \\
\text { bagus }\end{array}$ & Bagus & $\begin{array}{l}\text { Cukup } \\
\text { bagus }\end{array}$ & $\begin{array}{c}\text { Kurang } \\
\text { bagus }\end{array}$ & $\begin{array}{l}\text { Cukup } \\
\text { bagus }\end{array}$ \\
\hline 15 & $\begin{array}{l}\text { Toko Jasa } \\
\text { Saudara }\end{array}$ & $\begin{array}{l}\text { Cukup } \\
\text { bagus }\end{array}$ & Kurang bagus & $\begin{array}{l}\text { Cukup } \\
\text { bagus }\end{array}$ & $\begin{array}{c}\text { Kurang } \\
\text { bagus }\end{array}$ & $\begin{array}{l}\text { Tidak } \\
\text { bagus }\end{array}$ \\
\hline
\end{tabular}

Hasil dari konversi data penilaian alternatif dapat dilihat pada Tabel 4.5.

Tabel 5 : Nilai Angka Data Alternatif

\begin{tabular}{llccccc}
\hline No & Alternatif (A) & $\begin{array}{c}\text { Kualitas } \\
\text { Barang }\end{array}$ & $\begin{array}{c}\text { Harga } \\
\text { Terjangkau }\end{array}$ & $\begin{array}{c}\text { Tempat } \\
\text { Strategis }\end{array}$ & $\begin{array}{c}\text { Respon } \\
\text { Pelayanan }\end{array}$ & $\begin{array}{c}\text { Memberik } \\
\text { an Bonus }\end{array}$ \\
\cline { 3 - 7 } & & $\begin{array}{c}\text { Bobot }= \\
\mathbf{1}\end{array}$ & $\begin{array}{c}\text { Bobot }= \\
\mathbf{2}\end{array}$ & $\begin{array}{c}\text { Bobot }= \\
\mathbf{3}\end{array}$ & $\begin{array}{c}\text { Bobot }= \\
\mathbf{4}\end{array}$ & $\begin{array}{c}\text { Bobot }= \\
\mathbf{5}\end{array}$ \\
\hline 1 & Toko DW & 4 & 5 & 4 & 3 & 3 \\
\hline 2 & Toko Cemerlang & 3 & 2 & 2 & 3 & 3 \\
\hline 3 & Toko Persada Jaya & 4 & 3 & 4 & 3 & 2 \\
\hline 4 & Toko BBM & 4 & 3 & 3 & 3 & 2 \\
\hline 5 & Toko Sumber Terang & 3 & 2 & 3 & 4 & 3 \\
\hline 6 & Toko MM (Maju & 3 & 3 & 2 & 3 & 3 \\
\hline 7 & Toko Sumber Elektrik & 5 & 4 & 4 & 4 & 3 \\
\hline 8 & Toko SP (Sidi Pingai) & 4 & 3 & 3 & 3 \\
\hline
\end{tabular}

Jurnal KomtekInfo Vol : 7 No : 2||2020 


\begin{tabular}{cllllll}
\hline 9 & Toko Aneka Jaya & 3 & 4 & 4 & 3 & 3 \\
\hline 10 & Toko Amara & 4 & 3 & 4 & 3 & 3 \\
\hline 11 & Toko Rahmat Terang & 4 & 3 & 4 & 4 & 3 \\
\hline 12 & Toko BR & 4 & 4 & 3 & 4 & 3 \\
\hline 13 & Toko Nasional & 3 & 3 & 4 & 4 & 3 \\
\hline 14 & Toko Sinar Jelita & 5 & 4 & 3 & 2 & 3 \\
\hline 15 & Toko Jasa Saudara & 3 & 2 & 3 & 2 & 1 \\
\hline
\end{tabular}

\section{Melakukan Proses Normalisasi Matriks}

Pada tahap ini dilakukan perhitungan normalisasi matriks. Agar mempermudah dalam proses perhitungan dengan metode MAUT pada normalisasi maka ditentukan terlebih dahulu nilai tertinggi dan nilai terendah dari masing-masing kriteria, sehingga dapat dilihat pada Tabel 6.

\section{Tabel 6: Nilai Tertinggi Dan Nilai Terendah Setiap Kriteria}

\begin{tabular}{ccccccc}
\hline \multirow{2}{*}{ No } & \multirow{2}{*}{ Nilai } & \multicolumn{5}{c}{ Inisial Kriteria } \\
\cline { 3 - 7 } & & K1 & K2 & K3 & K4 & K5 \\
\hline 1 & Nilai Tertinggi & 5 & 5 & 4 & 4 & 4 \\
\hline 2 & Nilai Terendah & 3 & 2 & 2 & 2 & 1 \\
\hline
\end{tabular}

Berikut perhitungan matriks normalisasi distributor barang.

1. Nama Alternatif : Toko DW (A1)

$$
\begin{aligned}
& \mathrm{A} 1_{\mathrm{k} 1}=\frac{4-3}{5-3}=\frac{1}{2}=0,500 \\
& \mathrm{~A} 1_{\mathrm{k} 2}=\frac{5-2}{5-2}=\frac{3}{3}=1,000 \\
& \mathrm{~A} 1_{\mathrm{k} 3}=\frac{4-2}{4-2}=\frac{2}{2}=1,000 \\
& \mathrm{~A} 1_{\mathrm{k} 4}=\frac{3-2}{4-2}=\frac{1}{2}=0,500 \\
& \mathrm{~A} 1_{\mathrm{k} 5}=\frac{3-1}{4-1}=\frac{2}{3}=0,667
\end{aligned}
$$

Dari perhitungan normalisasi Toko DW di atas dapat dilihat nilai K1 (Kualitas Barang) $=0,500$, K2 $($ Harga Terjangkau $)=1,000, \mathrm{~K} 3($ Tempat Strategis $)=1,000, \mathrm{~K} 4($ Respon Pelayanan $)=0,500, \mathrm{~K} 5$ (Memberikan Bonus) $=0,667$.

2. Nama Alternatif : Toko Cemerlang (A2)

$$
\begin{aligned}
& \mathrm{A} 2_{\mathrm{k} 1}=\frac{3-3}{5-3}=\frac{0}{2}=0,000 \\
& \mathrm{~A} 2_{\mathrm{k} 2}=\frac{2-2}{5-2}=\frac{0}{3}=0,000 \\
& \mathrm{~A} 2_{\mathrm{k} 3}=\frac{2-2}{4-2}=\frac{0}{2}=0,000 \\
& \mathrm{~A} 2_{\mathrm{k} 4}=\frac{3-2}{4-2}=\frac{1}{2}=0,500 \\
& \mathrm{~A} 2_{\mathrm{k} 5}=\frac{3-1}{4-1}=\frac{2}{3}=0,667
\end{aligned}
$$

Dari perhitungan normalisasi Toko Cemerlang di atas dapat dilihat nilai K1 (Kualitas Barang) $=0,000$, $\mathrm{K} 2($ Harga Terjangkau $)=0,000, \mathrm{~K} 3$ (Tempat Strategis $)=0,000, \mathrm{k} 4($ Respon Pelayanan $)=0,500, \mathrm{k} 5$ (Memberikan Bonus) $=0,667$.

3. Nama Alternatif : Toko Persada Jaya (A3)

$$
\begin{aligned}
& \mathrm{A} 3_{\mathrm{k} 1}=\frac{4-3}{5-3}=\frac{1}{2}=0,500 \\
& \mathrm{~A} 3_{\mathrm{k} 2}=\frac{3-2}{5-2}=\frac{1}{3}=0,333
\end{aligned}
$$

Jurnal KomtekInfo Vol : 7 No : 2||2020 


$$
\begin{aligned}
& \mathrm{A} 3_{\mathrm{k} 3}=\frac{4-2}{4-2}=\frac{2}{2}=1,000 \\
& \mathrm{~A} 3_{\mathrm{k} 4}=\frac{3-2}{4-2}=\frac{1}{2}=0,500 \\
& \mathrm{~A} 3_{\mathrm{k} 5}=\frac{2-1}{4-1}=\frac{1}{3}=0,333
\end{aligned}
$$

Dari perhitungan normalisasi Toko Persada Jaya di atas dapat dilihat nilai K1 (Kualitas Barang) = $0,500, \mathrm{~K} 2($ Harga Terjangkau $)=0,333, \mathrm{~K} 3($ Tempat Strategis $)=1,000, \mathrm{~K} 4($ Respon Pelayanan $)=$ $0,500, \mathrm{~K} 5$ (Memberikan Bonus) $=0,333$.

4. Nama alternatif : Toko BBM (A4)

$$
\begin{aligned}
& \mathrm{A} 4_{\mathrm{k} 1}=\frac{4-3}{5-3}=\frac{1}{2}=0,500 \\
& \mathrm{~A} 4_{\mathrm{k} 2}=\frac{3-2}{5-2}=\frac{1}{3}=0,333 \\
& \mathrm{~A} 4_{\mathrm{k} 3}=\frac{3-2}{4-2}=\frac{1}{2}=0,500 \\
& \mathrm{~A} 4_{\mathrm{k} 4}=\frac{3-2}{4-2}=\frac{1}{2}=0,500 \\
& \mathrm{~A} 4_{\mathrm{k} 5}=\frac{4-1}{4-1}=\frac{3}{3}=1,000
\end{aligned}
$$

Dari perhitungan normalisasi Toko BBM di atas dapat dilihat nilai K1 (Kualitas Barang) $=0,500$, K2 $($ Harga Terjangkau $)=0,333, \mathrm{~K} 3($ Tempat Strategis $)=0,500, \mathrm{~K} 4($ Respon Pelayanan $)=0,500, \mathrm{~K} 5$ (Memberikan Bonus) $=1,000$.

5. Nama Alternatif : Toko Sumber Terang (A5)

$$
\begin{aligned}
& \mathrm{A} 5_{\mathrm{k} 1}=\frac{3-3}{5-3}=\frac{0}{2}=0,000 \\
& \mathrm{~A} 5_{\mathrm{k} 2}=\frac{2-2}{5-2}=\frac{0}{3}=0,000 \\
& \mathrm{~A} 5_{\mathrm{k} 3}=\frac{3-2}{4-2}=\frac{1}{2}=0,500 \\
& \mathrm{~A} 5_{\mathrm{k} 4}=\frac{4-2}{4-2}=\frac{2}{2}=1,000 \\
& \mathrm{~A} 5_{\mathrm{k} 5}=\frac{2-1}{4-1}=\frac{1}{3}=0,333
\end{aligned}
$$

Dari perhitungan normalisasi Toko Sumber Terang di atas dapat dilihat nilai K1 (Kualitas Barang) = $0,000, \mathrm{~K} 2($ Harga Terjangkau $)=0,000, \mathrm{~K} 3($ Tempat Strategis $)=0,500, \mathrm{~K} 4($ Respon Pelayanan $)=$ $1,000, \mathrm{~K} 5$ (Memberikan Bonus) = 0,333.

6. Nama Alternatif : Toko MM (Maju Mapan) (A6)

$$
\begin{aligned}
& \mathrm{A} 6_{\mathrm{k} 1}=\frac{3-3}{5-3}=\frac{0}{2}=0,000 \\
& \mathrm{~A} 6_{\mathrm{k} 2}=\frac{3-2}{5-2}=\frac{1}{3}=0,333 \\
& \mathrm{~A} 6_{\mathrm{k} 3}=\frac{2-2}{4-2}=\frac{0}{2}=0,000 \\
& \mathrm{~A} 6_{\mathrm{k} 4}=\frac{3-2}{4-2}=\frac{1}{2}=0,500 \\
& \mathrm{~A} 6_{\mathrm{k} 5}=\frac{1-1}{4-1}=\frac{0}{3}=0,000
\end{aligned}
$$

Dari perhitungan normalisasi Toko MM (Maju Mapan) di atas dapat dilihat nilai K1 (Kualitas Barang) $=0,000, \mathrm{~K} 2($ Harga Terjangkau $)=0,333, \mathrm{~K} 3($ Tempat Strategis $)=0,000, \mathrm{~K} 4($ Respon Pelayanan $)=$ $0,500, \mathrm{~K} 5$ (Memberikan Bonus) = 0,000.

7. Nama Alternatif : Toko Sumber Elektrik (A7) 


$$
\begin{aligned}
& \mathrm{A} 7_{\mathrm{k} 1}=\frac{5-3}{5-3}=\frac{2}{2}=1,000 \\
& \mathrm{~A} 7_{\mathrm{k} 2}=\frac{4-2}{5-2}=\frac{2}{3}=0,667 \\
& \mathrm{~A} 7_{\mathrm{k} 3}=\frac{4-2}{4-2}=\frac{2}{2}=1,000 \\
& \mathrm{~A} 7_{\mathrm{k} 4}=\frac{3-2}{4-2}=\frac{1}{2}=0,500 \\
& \mathrm{~A} 7_{\mathrm{k} 5}=\frac{3-1}{4-1}=\frac{2}{3}=0,667
\end{aligned}
$$

Dari perhitungan normalisasi Toko Sumber Elektrik di atas dapat dilihat nilai K1 (Kualitas Barang) = $1,000, \mathrm{~K} 2($ Harga Terjangkau $)=0,667, \mathrm{~K} 3($ Tempat Strategis $)=1,000, \mathrm{~K} 4($ Respon Pelayanan $)=$ $0,500, \mathrm{~K} 5$ (Memberikan Bonus) $=0,667$.

8. Nama Alternatif : Toko SP (Sidi Pingai) (A8)

$$
\begin{aligned}
& \mathrm{A} 8_{\mathrm{k} 1}=\frac{4-3}{5-3}=\frac{1}{2}=0,500 \\
& \mathrm{~A} 8_{\mathrm{k} 2}=\frac{3-2}{5-2}=\frac{1}{3}=0,333 \\
& \mathrm{~A} 8_{\mathrm{k} 3}=\frac{3-2}{4-2}=\frac{1}{2}=0,500 \\
& \mathrm{~A} 8_{\mathrm{k} 4}=\frac{4-2}{4-2}=\frac{2}{2}=1,000 \\
& \mathrm{~A} 8_{\mathrm{k} 5}=\frac{3-1}{4-1}=\frac{2}{3}=0,667
\end{aligned}
$$

Dari perhitungan normalisasi Toko SP (Sidi Pingai) di atas dapat dilihat nilai K1 (Kualitas barang) = $0,500, \mathrm{~K} 2($ Harga Terjangkau $)=0,333, \mathrm{~K} 3($ Tempat Strategis $)=0,500, \mathrm{~K} 4($ Respon Pelayanan $)=$ $1,000, \mathrm{~K} 5$ (Memberikan Bonus) $=0,667$.

9. Nama Alternatif : Toko Aneka Jaya (A9)

$$
\begin{aligned}
& \mathrm{A} 9_{\mathrm{k} 1}=\frac{3-3}{5-3}=\frac{0}{2}=0,000 \\
& \mathrm{~A} 9_{\mathrm{k} 2}=\frac{4-2}{5-2}=\frac{2}{3}=0,667 \\
& \mathrm{~A} 9_{\mathrm{k} 3}=\frac{4-2}{4-2}=\frac{2}{2}=1,000 \\
& \mathrm{~A} 9_{\mathrm{k} 4}=\frac{3-2}{4-2}=\frac{1}{2}=0,500 \\
& \mathrm{~A} 9_{\mathrm{k} 5}=\frac{3-1}{4-1}=\frac{2}{3}=0,667
\end{aligned}
$$

Dari perhitungan normalisasi Toko Aneka Jaya di atas dapat dilihat nilai K1 (Kualitas Barang) = $0,000, \mathrm{~K} 2($ Harga Terjangkau $)=0,667, \mathrm{~K} 3($ Tempat Strategis $)=1,000, \mathrm{~K} 4($ Respon Pelayanan $)=$ $0,500, \mathrm{~K} 5$ (Memberikan Bonus) $=0,667$.

10. Nama Alternatif : Toko Amara (A10)

$$
\begin{aligned}
& \mathrm{A} 10_{\mathrm{k} 1}=\frac{4-3}{5-3}=\frac{1}{2}=0,500 \\
& \mathrm{~A} 10_{\mathrm{k} 2}=\frac{3-2}{5-2}=\frac{1}{3}=0,333 \\
& \mathrm{~A} 10_{\mathrm{k} 3}=\frac{4-2}{4-2}=\frac{2}{2}=1,000 \\
& \mathrm{~A} 10_{\mathrm{k} 4}=\frac{3-2}{4-2}=\frac{1}{2}=0,500 \\
& \mathrm{~A} 10_{\mathrm{k} 5}=\frac{3-1}{4-1}=\frac{2}{3}=0,667
\end{aligned}
$$


Dari perhitungan normalisasi Toko Amara di atas dapat dilihat nilai K1 (Kualitas Barang) $=0,500$, K2 $($ Harga Terjangkau $)=0,333, \mathrm{~K} 3($ Tempat Strategis $)=1,000, \mathrm{~K} 4($ Respon Pelayanan $)=0,500, \mathrm{~K} 5$ (Memberikan Bonus) $=0,667$.

11. Nama Alternatif : Toko Rahmat Terang (A11)

$$
\begin{aligned}
& \mathrm{A} 11_{\mathrm{k} 1}=\frac{4-3}{5-3}=\frac{1}{2}=0,500 \\
& \mathrm{~A} 11_{\mathrm{k} 2}=\frac{3-2}{5-2}=\frac{1}{3}=0,333 \\
& \mathrm{~A} 11_{\mathrm{k} 3}=\frac{4-2}{4-2}=\frac{2}{2}=1,000 \\
& \mathrm{~A} 11_{\mathrm{k} 4}=\frac{4-2}{4-2}=\frac{2}{2}=1,000 \\
& \mathrm{~A} 11_{\mathrm{k} 5}=\frac{3-1}{4-1}=\frac{2}{3}=0,667
\end{aligned}
$$

Dari perhitungan normalisasi Toko Rahmat Terang di atas dapat dilihat nilai K1 (Kualitas Barang) = $0,500, \mathrm{~K} 2($ Harga Terjangkau $)=0,333, \mathrm{~K} 3($ Tempat Strategis $)=1,000, \mathrm{~K} 4($ Respon Pelayanan $)=$ $1,000, \mathrm{~K} 5$ (Memberikan Bonus) $=0,667$.

12. Nama Alternatif : Toko BR (A12)

$$
\begin{aligned}
& \mathrm{A} 12_{\mathrm{k} 1}=\frac{4-3}{5-3}=\frac{1}{2}=0,500 \\
& \mathrm{~A} 12_{\mathrm{k} 2}=\frac{4-2}{5-2}=\frac{2}{3}=0,667 \\
& \mathrm{~A} 12_{\mathrm{k} 3}=\frac{3-2}{4-2}=\frac{1}{2}=0,500 \\
& \mathrm{~A} 12_{\mathrm{k} 4}=\frac{4-2}{4-2}=\frac{2}{2}=1,000 \\
& \mathrm{~A} 12_{\mathrm{k} 5}=\frac{3-1}{4-1}=\frac{2}{3}=0,667
\end{aligned}
$$

Dari perhitungan normalisasi Toko BR di atas dapat dilihat nilai K1 (Kualitas Barang) $=0,500, \mathrm{~K} 2$ $($ Harga Terjangkau $)=0,667, \mathrm{~K} 3($ Tempat Strategis $)=0,500, \mathrm{~K} 4($ Respon Pelayanan $)=1,000, \mathrm{~K} 5$ (Memberikan Bonus) $=0,667$.

13. Nama Alternatif : Toko Nasional (A13)

$$
\begin{aligned}
& \mathrm{A} 13_{\mathrm{k} 1}=\frac{3-3}{5-3}=\frac{0}{2}=0,000 \\
& \mathrm{~A} 13_{\mathrm{k} 2}=\frac{3-2}{5-2}=\frac{1}{3}=0,333 \\
& \mathrm{~A} 13_{\mathrm{k} 3}=\frac{4-2}{4-2}=\frac{2}{2}=1,000 \\
& \mathrm{~A} 13_{\mathrm{k} 4}=\frac{4-2}{4-2}=\frac{2}{2}=1,000 \\
& \mathrm{~A} 13_{\mathrm{k} 5}=\frac{3-1}{4-1}=\frac{2}{3}=0,667
\end{aligned}
$$

Dari perhitungan normalisasi Toko Nasional di atas dapat dilihat nilai K1 (Kualitas Barang) $=0,000$, K2 $($ Harga Terjangkau $)=0,333, \mathrm{~K} 3($ Tempat Strategis $)=1,000, \mathrm{~K} 4($ Respon Pelayanan $)=1,000, \mathrm{~K} 5$ (Memberikan Bonus) $=0,667$.

14. Nama Alternatif : Toko Sinar Jelita (A14)

$$
\begin{aligned}
& \mathrm{A} 14_{\mathrm{k} 1}=\frac{5-3}{5-3}=\frac{2}{2}=1,000 \\
& \mathrm{~A} 14_{\mathrm{k} 2}=\frac{4-2}{5-2}=\frac{2}{3}=0,667 \\
& \mathrm{~A} 14_{\mathrm{k} 3}=\frac{3-2}{4-2}=\frac{1}{2}=0,500
\end{aligned}
$$




$$
\begin{aligned}
& \mathrm{A} 14_{\mathrm{k} 4}=\frac{2-2}{4-2}=\frac{0}{2}=0,000 \\
& \mathrm{~A} 14_{\mathrm{k} 5}=\frac{3-1}{4-1}=\frac{2}{3}=0,667
\end{aligned}
$$

Dari perhitungan normalisasi Toko Sinar Jelita di atas dapat dilihat nilai K1 (Kualitas Barang) = $1,000, \mathrm{~K} 2$ (Harga Terjangkau) $=0,667, \mathrm{~K} 3$ (Kestabilan Tempat Strategis) $=0,500, \mathrm{~K} 4$ (Respon Pelayanan $)=0,000, \mathrm{~K} 5$ (Memberikan Bonus) $=0,667$.

15. Nama Alternatif : Toko Jasa Saudara (A15)

$$
\begin{aligned}
& \mathrm{A} 15_{\mathrm{k} 1}=\frac{3-3}{5-3}=\frac{0}{2}=0,000 \\
& \mathrm{~A} 15_{\mathrm{k} 2}=\frac{2-2}{5-2}=\frac{0}{3}=0,000 \\
& \mathrm{~A} 15_{\mathrm{k} 3}=\frac{3-2}{4-2}=\frac{1}{2}=0,500 \\
& \mathrm{~A} 15_{\mathrm{k} 4}=\frac{2-2}{4-2}=\frac{0}{2}=0,000 \\
& \mathrm{~A} 15_{\mathrm{k} 5}=\frac{1-1}{4-1}=\frac{0}{3}=0,000
\end{aligned}
$$

Dari perhitungan normalisasi Toko Jasa Saudara di atas dapat dilihat nilai K1 (Kualitas Barang) = $0,000, \mathrm{~K} 2($ Harga Terjangkau $)=0,000, \mathrm{~K} 3($ Tempat Strategis $)=0,500, \mathrm{~K} 4($ Respon Pelayanan $)=$ $0,000, \mathrm{~K} 5$ (Memberikan Bonus) $=0,000$.

Setelah proses perhitungan normalisasi matriks dilakukan maka hasil normalisasi dapat dilihat pada Tabel 7.

Tabel 7 : Hasil Normalisasi Matriks

\begin{tabular}{clccccc}
\hline No & \multicolumn{1}{c}{ Alternatif (A) } & K1 & K2 & K3 & K4 & K5 \\
\hline 1 & Toko DW & 0,500 & 1,000 & 1,000 & 0,500 & 0,667 \\
\hline 2 & Toko Cemerlang & 0,000 & 0,000 & 0,000 & 0,500 & 0,667 \\
\hline 3 & Toko Persada Jaya & 0,500 & 0,333 & 1,000 & 0,500 & 0,333 \\
\hline 4 & Toko BBM & 0,500 & 0,333 & 0,500 & 0,500 & 1,000 \\
\hline 5 & Toko Sumber Terang & 0,000 & 0,000 & 0,500 & 1,000 & 0,333 \\
\hline 6 & Toko MM (Maju Mapan) & 0,000 & 0,333 & 0,000 & 0,500 & 0,000 \\
\hline 7 & Toko Sumber Elektrik & 1,000 & 0,667 & 1,000 & 0,500 & 0,667 \\
\hline 8 & Toko SP (Sidi Pingai) & 0,500 & 0,333 & 0,500 & 1,000 & 0,667 \\
\hline 9 & Toko Aneka Jaya & 0,000 & 0,667 & 1,000 & 0,500 & 0,667 \\
\hline 10 & Toko Amara & 0,500 & 0,333 & 1,000 & 0,500 & 0,667 \\
\hline 11 & Toko Rahmat Terang & 0,500 & 0,333 & 1,000 & 1,000 & 0,667 \\
\hline 12 & Toko BR & 0,500 & 0,667 & 0,500 & 1,000 & 0,667 \\
\hline 13 & Toko Nasional & 0,000 & 0,333 & 1,000 & 1,000 & 0,667 \\
\hline 14 & Toko Sinar Jelita & 1,000 & 0,667 & 0,500 & 0,000 & 0,667 \\
\hline 15 & Toko Jasa Saudara & 0,000 & 0,000 & 0,500 & 0,000 & 0,000 \\
\hline
\end{tabular}

Melakukan Penjumlahan Hasil Perkalian dari Hasil Normalisasi dengan Bobot Kriteria

Setelah hasil normalisasi matriks didapatkan, maka tahap selanjutnya dilakukan penjumlahan hasil perkalian dari hasil normalisasi pada Tabel 4.7 dengan bobot kriteria yang merujuk Tabel 5. Sehingga dilakukan proses perhitungan dengan menggunakan persamaan (2). Berikut perhitungan perkalian matriks normalisasi.

1. Nama Alternatif : Toko DW (A1)

$$
\begin{aligned}
\mathrm{A} 1 & =(1 * 0,500)+(2 * 1,000)+(3 * 1,000)+(4 * 0,500)+(5 * 0,667) \\
& =0,500+2,000+3,000+2,000+3,335=10,84
\end{aligned}
$$

Jurnal KomtekInfo Vol : 7 No : 2|| 2020 
2. Nama Alternatif : Toko Cemerlang (A2)

$$
\begin{aligned}
\mathrm{A} 2 & =(1 * 0,000)+(2 * 0,000)+(3 * 0,000)+(4 * 0,500)+(5 * 0,667) \\
& =0,000+0,000+0,000+2,000+3,335=5,34
\end{aligned}
$$

3. Nama Alternatif : Toko Persada Jaya (A3)

$$
\begin{aligned}
\mathrm{A} 3 & =(1 * 0,500)+(2 * 0,333)+(3 * 1,000)+(4 * 0,500)+\left(5^{*} 0,333\right) \\
& =0,500+0,666+3,000+2,000+1,665=7,83
\end{aligned}
$$

4. Nama Alternatif : Toko BBM (A4)

$$
\begin{aligned}
\mathrm{A} 4 & =(1 * 0,500)+(2 * 0,333)+(3 * 0,500)+(4 * 0,500)+(5 * 1,000) \\
& =0,500+0,666+1,500+2,000+5,000=9,67
\end{aligned}
$$

5. Nama Alternatif : Toko Sumber Terang (A5)

$$
\begin{aligned}
\mathrm{A} 5 & =(1 * 0,000)+(2 * 0,000)+(3 * 0,500)+(4 * 1,000)+(5 * 0,333) \\
& =0,000+0,000+1,500+4,000+1,665=7,17
\end{aligned}
$$

6. Nama Alternatif : Toko MM (Maju Mapan) (A6)

$$
\begin{aligned}
\mathrm{A} 6 & =(1 * 0,000)+(2 * 0,333)+(3 * 0,000)+(4 * 0,500)+(5 * 0,000) \\
& =0,000+0,666+0,000+2,000+0,000=2,67
\end{aligned}
$$

7. Nama Alternatif : Toko Sumber Elektrik (A7)

$$
\begin{aligned}
\mathrm{A} 7 & =(1 * 1,000)+(2 * 0,667)+(3 * 1,000)+(4 * 0,500)+(5 * 0,667) \\
& =1,000+1,334+3,000+2,000+3,335=10,67
\end{aligned}
$$

8. Nama Alternatif : Toko SP (Sidi Pingai) (A8)

$$
\begin{aligned}
\mathrm{A} 8 & =(1 * 0,500)+(2 * 0,333)+(3 * 0,500)+(4 * 1,000)+(5 * 0,667) \\
& =0,500+0,666+1,500+4,000+3,335=10.00
\end{aligned}
$$

9. Nama Alternatif : Toko Aneka Jaya (A9)

$$
\begin{aligned}
\mathrm{A} 9 & =(1 * 0,000)+(2 * 0,667)+(3 * 1,000)+(4 * 0,500)+(5 * 0,667) \\
& =0,000+1,334+3,000+2,000+3,335=9,67
\end{aligned}
$$

10. Nama Alternatif : Toko Amara (A10)

$$
\begin{aligned}
\mathrm{A} 10 & =(1 * 0,500)+(2 * 0,333)+(3 * 1,000)+(4 * 0,500)+(5 * 0,667) \\
& =0,500+0,666+3,000+2,000+3,335=9,50
\end{aligned}
$$

11. Nama Alternatif : Toko Rahmat Terang (A11)

$$
\begin{aligned}
\mathrm{A} 11 & =(1 * 0,500)+(2 * 0,333)+(3 * 1,000)+(4 * 1,000)+(5 * 0,667) \\
& =0,500+0,666+3,000+4,000+3,335=11,50
\end{aligned}
$$

12. Nama Alternatif : Toko BR (A12)

$$
\begin{aligned}
\mathrm{A} 12 & =(1 * 0,500)+(2 * 0,667)+(3 * 0,500)+(4 * 1,000)+(5 * 0,667) \\
& =0,500+1,334+1,500+4,000+3,335=10,67
\end{aligned}
$$

13. Nama Alternatif : Toko Nasional (A13)

$$
\begin{aligned}
\mathrm{A} 13 & =(1 * 0,000)+(2 * 0,333)+(3 * 1,000)+(4 * 1,000)+(5 * 0,667) \\
& =0,000+0,666+3,000+4,000+3,335=11,00
\end{aligned}
$$

14. Nama Alternatif : Toko Sinar Jelita (A14)

$$
\begin{aligned}
\mathrm{A} 14 & =(1 * 1,000)+(2 * 0,667)+(3 * 0,500)+(4 * 0,000)+(5 * 0,667) \\
& =1,000+1,334+1,500+0,000+3,335=7,17
\end{aligned}
$$


15. Nama Alternatif : Toko Jasa Saudara (A15)

$$
\begin{aligned}
\mathrm{A} 15 & =(1 * 0,000)+(2 * 0,000)+(3 * 0,500)+(4 * 0,000)+(5 * 0,000) \\
& =0,000+0,000+1.500+0,000+0,000=1,50
\end{aligned}
$$

Setelah melakukan perkalian matriks normalisasi dengan bobot maka hasil perhitungan didapatkan pada setiap alternatif dapat dilihat pada Tabel 8.

Tabel 8: Hasil Perkalian Matriks Normalisasi dengan Bobot

\begin{tabular}{clc}
\hline & \multicolumn{1}{c}{ Alternatif (A) } & Hasil \\
\hline 1 & Toko DW & 10,84 \\
\hline 2 & Toko Cemerlang & 5,34 \\
\hline 3 & Toko Persada Jaya & 7,83 \\
\hline 4 & Toko BBM & 9,67 \\
\hline 5 & Toko Sumber Terang & 7,17 \\
\hline 6 & Toko MM (Maju Mapan) & 2,67 \\
\hline 7 & Toko Sumber Elektrik & 10,67 \\
\hline 8 & Toko SP (Sidi Pingai) & 10,00 \\
\hline 9 & Toko Aneka Jaya & 9,67 \\
\hline 10 & Toko Amara & 9,50 \\
\hline 11 & Toko Rahmat Terang & 11,50 \\
\hline 12 & Toko BR & 10,67 \\
\hline 13 & Toko Nasional & 11,00 \\
\hline 14 & Toko Sinar Jelita & 7,17 \\
\hline 15 & Toko Jasa Saudara & 1,50 \\
\hline
\end{tabular}

\section{Perangkingan}

Perkalian pada hasil perhitungan matriks normalisasi dengan bobot yang ada pada Tabel 4.10 akan dibuatkan perangkingan yang mengurutkan nilai tertinggi ke nilai terendah, sehingga pihak toko mengetahui distributor terbaik pada pemilihan distributor barang. Hasil perangkingan pada Tabel 9 sebagai berikut.

Tabel 9 : Perangkingan

\begin{tabular}{rlcc}
\hline No & \multicolumn{1}{c}{ Nama Distributor } & Hasil & Rangking \\
\hline 1 & Toko Rahmat Terang & 11,50 & 1 \\
\hline 2 & Toko Nasional & 11,00 & 2 \\
\hline 3 & Toko DW & 10,84 & 3 \\
\hline 4 & Toko Sumber Elektrik & 10,67 & 4 \\
\hline 5 & Toko BR & 10,67 & 5 \\
\hline 6 & Toko SP (Sidi Pingai) & 10,00 & 6 \\
\hline 7 & Toko BBM & 9,67 & 7 \\
\hline 8 & Toko Aneka Jaya & 9,67 & 8 \\
\hline 9 & Toko Amara & 9,50 & 9 \\
\hline 10 & Toko Persada Jaya & 7,83 & 10 \\
\hline 11 & Toko Sinar Jelita & 7,17 & 12 \\
\hline 12 & Toko Sumber Terang & 7,17 & 13 \\
\hline 13 & Toko Cemerlang & 5,34 & 14 \\
\hline 14 & Toko MM (Maju Mapan) & 2,67 & 15 \\
\hline 15 & Toko Jasa Saudara & 1,50 & \\
\hline
\end{tabular}

Pada Tabel diatas dapat dilihat bahwa nilai tertinggi adalah Toko Rahmat Terang dengan hasil 11,50 yang menempati peringkat terbaik (rangking 1), karena mendapatkan jumlah hasil yang lebih tinggi dari empat belas distributor lainnya.

\section{Keputusan Pemilihan Distributor}


Setelah hasil perangkingan diperoleh dilakukan proses pengambilan keputusan berdasarkan dengan 5 distributor yang telah ditetapkan oleh Toko Serba Serbi. Hasil perangkingan dari di atas maka dipilih lima peringkat distributor terbaik dari seluruh alternatif yang dimasukkan. Di mana hasil akhir dari keputusan distributor barang terbaik pada penelitian ini dapat dilihat pada Tabel 10.

Tabel 10 : Hasil Keputusan Distributor Barang

\begin{tabular}{clll}
\hline No & \multicolumn{1}{c}{ Nama Distributor } & Hasil & Keputusan \\
\hline 1 & Toko Rahmat Terang & 11,50 & Terpilih 1 \\
\hline 2 & Toko Nasional & 11,00 & Terpilih 2 \\
\hline 3 & Toko DW & 10,84 & Terpilih 3 \\
\hline 4 & Toko Sumber Elektrik & 10,67 & Terpilih 4 \\
\hline 5 & Toko BR & 10,67 & Terpilih 5 \\
\hline
\end{tabular}

Hasil dari analisis dengan metode MAUT pada kasus pemilihan distributor dapat menghasilkan pilihan yang lebih objektif dengan keputusan yang diambil 5 distributor dengan nilai tertinggi untuk pemilihan distributor barang terbaik pada Toko Serba Serbi berdasarkan surat keterangan yang diberikan Toko Serba Serbi.

\section{Hasil Pengujian}

Pengujian menggunakan sistem dilakukan untuk mengetahui proses analisa dan perancangan sudah sesuai dengan implementasi menggunakan program. Pengujian sistem ini dilakukan terhadap alternatif dalam proses analisa data, data alternatif yang digunakan dalam analisa yaitu sebanyak 15 alternatif. Hasil yang tertinggi akan menjadi acuan dalam pemilihan distributor barang terbaik pada Toko Serba Serbi. Hasil pengujian dapat dilihat pada Tabel 11 Hasil Pengujian.

Tabel 11 : Hasil Pengujian

\begin{tabular}{clllll}
\hline NO & Hasil Metode MAUT & \multicolumn{1}{c}{ Peringkat } & $\begin{array}{c}\text { Data Toko Serba } \\
\text { Serbi }\end{array}$ & Peringkat & Perbandingan \\
\hline 1 & Toko Rahmat Terang & Rangking 1 & Toko Rahmat Terang & Rangking 1 & Hasil Sama \\
\hline 2 & Toko Nasional & Rangking 2 & Toko Nasional & Rangking 2 & Hasil Sama \\
& & & & & \\
\hline 3 & Toko DW & Rangking 3 & Toko DW & Rangking 3 & Hasil Sama \\
& & & & & \\
\hline 4 & Toko Sumber Elektrik & Rangking 4 & Toko BR & Rangking 4 & Hasil Tidak Sama \\
\hline 5 & Toko BR & Rangking 5 & Toko Sumber Elektrik & Rangking 5 & Hasil Tidak Sama \\
\hline 6 & Toko SP (Sidi Pingai) & Rangking 6 & Toko SP (Sidi Pingai) & Rangking 6 & Hasil Sama \\
\hline 7 & Toko BBM & Rangking 7 & Toko BBM & Rangking 7 & Hasil Sama \\
\hline 8 & Toko Aneka Jaya & Rangking 8 & Toko Aneka Jaya & Rangking 8 & Hasil Sama \\
\hline 9 & Toko Amara & Rangking 9 & Toko Amara & Rangking 9 & Hasil Sama \\
& & & & & \\
\hline 10 & Toko Persada Jaya & Rangking 10 & Toko Persada Jaya & Rangking 10 & Hasil Sama \\
\hline 11 & Toko Sinar Jelita & Rangking 11 & Toko Sinar Jelita & Rangking 11 & Hasil Sama \\
\hline 12 & Toko Sumber Terang & Rangking 12 & Toko Sumber Terang & Rangking 12 & Hasil Sama \\
\hline 13 & Toko Cemerlang & Rangking 13 & Toko Cemerlang & Rangking 13 & Hasil Sama \\
\hline 14 & Toko MM (Maju & Rangking 14 & Toko MM (Maju & Rangking 14 & Hasil Sama \\
& Mapan) & Mapan) & Toko Jasa Saudara & Rangking 15 & Hasil Sama \\
\hline 15 & Toko Jasa Saudara & Rangking 15 & Tama & & \\
\hline & & & & & \\
\hline
\end{tabular}

Dari hasil pengujian pada Tabel di atas Hasil Pengujian, dapat dilihat perbedaan antara hasil yang didapatkan melalui metode MAUT dengan hasil yang didapatkan oleh pihak Toko Serba Serbi. Dari 15 alternatif yang ada ditemukan 2 hasil pengolahan data yang memiliki perbedaan. Sedangkan untuk keakuratan Sistem Pendukung Keputusan mengenai pemilihan distributor barang dengan hasil dari pihak toko ditemukan 13 hasil pengolahan data yang memiliki kesamaan. Hasil penelitian ini 
menggunakan metode Multi Attribute Utility Theory (MAUT) dapat menentukan 5 distibutor barang terbaik, dengan tingkat akurasi yaitu $86,67 \%$ terhadap distributor barang dan sesuai dengan realisasi data uji. Maka penelitian ini meghasilkan penetapan kriteria yang sangat baik. Sehingga penelitian ini dapat dijadikan acuan dalam pemilihan distributor barang terbaik terhadap penentuan kriteria dan bobot kriteria yang sangat tepat pada Toko Serba Serbi. Hasil dari penelitian ini dapat dijadikan dasar untuk mengambil keputusan dalam menentukan 5 distibutor barang terbaik.

\section{Kesimpulan}

Dari uraian hasil dan pembahasan yang dilakukan maka dapat diambil kesimpulannya adalah dengan metode MAUT dapat diterapkan pada Sistem Pendukung Keputusan dengan memperhatikan kriteriakriteria yang dilakukan penilaian pembobotan dalam pemilihan distributor barang terbaik. Dari analisa didapat hasil perhitungan 5 kriteria yaitu (kualitas barang, harga terjangkau, tempat strategis, respon pelayanan, memberikan bonus) dan bobot preferensi yang sudah ditentukan. Penerapan metode MAUT pada Sistem Pendukung Keputusan menghasilkan alternatif yang memiliki distributor barang terbaik (rangking 1) adalah Toko Rahmat Terang dengan nilai 11,50. Dengan menggunakan data 15 calon distributor barang, hasil pengujian tersebut mendapatkan 5 distributor terbaik dan dibandingkan dengan surat keputusan data distributor yang ada pada Toko Serba Serbi dengan menghasilkan tingkat akurasi yaitu $86,67 \%$, maka kriteria yang ditetapkan oleh pihak toko dapat dijadikan acuan dalam pemilihan distributor barang terbaik.

\section{Referensi}

[1] Agustina, Y., Dalimunthe, N., Parlina, I., dan Lubis, M. R. (2018). "Penerapan Metode Maut Pada Pemilihan Bimbingan Intensif Terbaik Di Pematangsiantar" KOMIK (Konferensi Nasional Teknologi Informasi dan Komputer), vol. 2, no. 1.

[2] Aini, N., Agus F. (2017). "Penerapan Metode Weighted Product Dan Analytic Hierarchy Process Untuk Pemilihan Koperasi Berprestasi” Jurnal Infotel (Informatika - Telekomunikasi - Elektronika), vol. 9, no. 2. https://doi.org/10.20895/infotel.v9i2.184

[3] Fajirwan, D., Arhami, M., dan Amalia, I. (2018). "Sistem Pendukung Keputusan Penerimaan Bantuan Renovasi Rumah Dhuafa Menggunakan Metode Multi Attribute Utility Theory” Jurnal Infomedia, vol. 3, no. 2. https://doi.org/10.30811/jim.v3i2.713

[4] Gultom, D. R., \& Waruwu, F. T. (2019). "Sistem Pendukung Keputusan Penempatan Prajurit Tni Ad Di Daerah Perbatasan Menggunakan Metode Multi Attribute Utility Theory (Studi Kasus: Yonif 121 Macan Kumbang, Galang, Sumatera Utara)" Jurnal Pelita Informatika, vol. 18, no. 1.

[5] Hadinata, N. (2018). "Implementasi Metode Multi Attribute Utility Theory (MAUT) Pada Sistem Pendukung Keputusan dalam Menentukan Penerima Kredit”. Jurnal Sisfokom (Sistem Informasi Dan Komputer), vol. 7, no. 2. https://doi.org/10.32736/sisfokom.v7i2.562

[6] Hariyanto, R. M., \& Maslihah. (2017). "Sistem Pendukung Keputusan Seleksi Pemilihan Kepala Bagian Perum Damri Surabaya" Information Technology Journal, vol. 3, no. 2.

[7] Imam, C., Santony, J., dan Yuhandri. (2019). "Sistem Pendukung Keputusan Spesifikasi Biji Jagung Berkualitas Terbaik Dengan Metode Multi Attribute Utility Theory" UPI YPTK Jurnal KomTekInfo, vol. 5, no. 3. https://doi.org/10.29165/komtekinfo.v5i2

[8] indoworx.com (2017), Pengertian Distributor, Suplier, Agen, Reseller dan Dropshipper, (Updated 09 Nov 20017) Available at: https://www.indoworx.com

[9] Nas, C., Defit, S., Santoni, J. (2018). "Evaluasi Mutasai Jabatan Anggota Kepolisian Menggunakan Metode Profile Matching dan Multi Attribute Utility Theory” Jurnal Sains, Teknologi dan Industri, vol. 16, no. 1.

[10] Nasyuha, A. H. (2019). "Sistem Pendukung Keputusan Menentukan Pemberian Pinjaman Modal dengan Metode Multi Attribute Utility Theory" Jurnal Media Informatika Budidarma, vol. 3, no. 2, http://dx.doi.org/10.30865/mib.v3i2.1093

[11] Nofriansyah, D., \& Defit, S. (2017). "Multi Criteria Decision Making (MCDM) Pada System Pendukung Keputusan". Yogyakarta : Deepublish 
[12] Pergher, I., dan de Almeida, A. T. (2018). A multi-attribute, rank-dependent utility model for selecting dispatching rules. Journal of Manufacturing Systems. Elsevier $\quad$ B.V. https://doi.org/10.1016/j.jmsy.2018.01.007

[13] Rahman, M., Na'am, J., \& Santony, J. (2019). "Pemilihan Peserta Lomba Kompetensi Siswa Menggunakan Metode TOPSIS ”. KomtekInfo, $\quad$ vol. 5, $\quad$ no. 3. https://doi.org/https://doi.org/10.29165/komtekinfo.v5i3.150

[14] Sarah, F., Devianto, D., Ginting, B. (2017). "Pemilihan Distributor Oleh Cv. Sinar Matahari Pariaman Menggunakan Metode Analytical Hierarchy Process Dan Goal Programming" Jurnal Matematika UNAND, vol. VI, no. 4.

[15] Sari, D. R., Windarto, A. P., Hartama, D., \& Solikhun, S. (2018). "Sistem Pendukung Keputusan untuk Rekomendasi Kelulusan Sidang Skripsi Menggunakan Metode AHP-TOPSIS” Jurnal Teknologi Dan Sistem Komputer, vol. 6, no. 1. https://doi.org/10.14710/jtsiskom.6.1.2018.1-6

[16] Sari, R. N., dan R. S. Hayati. (2019). "Penerapan Metode Multi Attribute Utility Theory (MAUT) Dalam Pemilihan Rumah Kost" Jurnal Sains Komputer \& Informatika (J-SAKTI), vol. 3, no. 2. http://dx.doi.org/10.30645/j-sakti.v3i2.144

[17] Sasongko, A., Astuti, I., F., \& Maharani, S. (2017). "Pemilihan Karyawan Baru Dengan Metode Ahp (Analytic Hierarchy Process)" Jurnal Informatika Mulawarman, vol. 12, no.2. http://dx.doi.org/10.30872/jim.v12i2.650

[18] Satria, E., Atina, N., Simbolon, M. E., \&Windarto, A. P. (2018). “Spk: Algoritma Multi-Attribute Utility Theory (Maut) Pada Destinasi Tujuan Wisata Lokal Di Kota Sidamanik” Computer Engineering, Science and System Journal, vol. 3, no. 2. https://doi.org/10.24114/cess.v3i2.9954

[19] Sudarmadi, A., Santoso, E., dan Sutrisno. (2017). "Sistem Pendukung Keputusan Pemilihan Personel Homeband Universitas Brawijaya Menggunakan Metode Profile Matching" Jurnal Pengembangan Teknologi Informasi dan Ilmu Komputer, vol. 1, no. 12.

[20] Suner, A., Oruc, O. E., Buke, C., Ozkaya, H. D., \& Kitapcioglu, G. (2017). "Evaluation of infectious diseases and clinical microbiology specialists' preferences for hand hygiene: Analysis using the multiattribute utility theory and the analytic hierarchy process methods" BMC Medical Informatics and Decision Making, Vol. 17 No.1. https://doi.org/10.1186/s12911-017-0528-Z

[21] Taufiq, R., \& Fahlevi, M., R. (2017). "Perancangan Sistem Pendukung Keputusan Penerimaan Beasiswa Mengunakan Metode Saw Pada Smp Yuppentek 1 Legok" Jurnal Teknik: Universitas Muhammadiyah Tangerang, vol. 6, no. 2. http://dx.doi.org/10.31000/jt.v6i2.447

[22] Umar, K. A., Lutfi, S., dan Tempola, F. (2019). "Sistem Pendukung Keputusan Rekomendasi Webhosting Pada Kantor Media Online Suaramu.Co Menggunakan Metode Multi Attribute Utility Theory (Maut)" Jurnal Teknologi Informatika (J-TIFA), vol. 2, no. 1. 